Correction

\title{
Correction: Sofan, P.; Bruce, D.; Jones, E.; Marsden, J. Detection and Validation of Tropical Peatland Flaming and Smouldering Using Landsat-8 SWIR and TIRS Bands. Remote Sens. 2019, 11, 465
}

\author{
Parwati Sofan $1,2, *\left(\mathbb{D}\right.$, David Bruce $\left.{ }^{3}{ }^{(}\right)$, Eriita Jones ${ }^{4}$ and Jackie Marsden ${ }^{5}$ \\ 1 PhD Candidate, University of South Australia (UniSA), Adelaide, SA 5000, Australia \\ 2 Remote Sensing Application Center of Indonesian Institute of Aeronautics and Space (LAPAN), \\ Jakarta 13710, Indonesia \\ 3 Natural and Built Environments Research Centre, University of South Australia, Adelaide, SA 5000, \\ Australia; david.bruce@unisa.edu.au \\ 4 Computational Learning Systems Laboratory, School of IT and Mathematical Sciences, \\ University of South Australia, Mawson Lakes, SA 5095, Australia; eriita.jones@unisa.edu.au \\ 5 Imagery, Landgate, Midland, WA 6056, Australia; Jackie.Marsden@landgate.wa.gov.au \\ * Correspondence: sofpy001@mymail.unisa.edu.au
}

Received: 10 April 2019; Accepted: 26 April 2019; Published: 28 April 2019

check for updates

The authors wish to make the following corrections to this paper [1]:

Due to a technical error at the Editorial Office, Equation (2) of manuscript [1] is wrong in the published paper:

$$
\operatorname{FAR}(\%)=\frac{\mathrm{a}_{1}+\mathrm{b}_{2}+\mathrm{c}_{3}+\mathrm{d}_{4}}{\Sigma} \times 100
$$

The correct version of the equation should be

$$
\operatorname{FAR}(\%)=\frac{d_{1}}{\mathrm{~T} \Sigma_{\mathrm{S}}}, \frac{d_{2}}{\mathrm{~T} \Sigma_{\mathrm{FS}}}, \frac{d_{3}}{\mathrm{~T} \Sigma_{\mathrm{F}}}, \frac{d_{4}}{\mathrm{~T} \Sigma_{N o n}} \times 100
$$

We apologize for any inconvenience caused to authors or readers of Remote Sensing.

\section{Reference}

1. Sofan, P.; Bruce, D.; Jones, E.; Marsden, J. Detection and Validation of Tropical Peatland Flaming and Smouldering Using Landsat-8 SWIR and TIRS Bands. Remote Sens. 2019, 11, 465. [CrossRef]

(C) 2019 by the authors. Licensee MDPI, Basel, Switzerland. This article is an open access article distributed under the terms and conditions of the Creative Commons Attribution (CC BY) license (http://creativecommons.org/licenses/by/4.0/). 